\title{
Penguatan Pendidikan Karakter Mandiri Anak Berkebutuhan Khusus Tunagrahita di Panti Sosial Bina Grahita "Harapan Ibu" Padang
}

\author{
Melda Neli, Junaidi Indrawadi, Isnarmi \\ Prodi Pendidikan Pancasila dan Kewarganegaraan \\ Universitas Negeri Padang \\ E-mail: nelimelda.20maret@gmail.com
}

\section{ABSTRAK}

Penelitian ini dilatarbelakangi oleh pentingnya penguatan pendidikan karakter mandiri anak berkebutuhan khusus. Tujuan penelitian untuk mengidentifikasi bentukbentuk, hambatan dan upaya pendidik dan pembimbing dalam penguatan pendidikan karakter mandiri anak tunagrahita. Jenis penelitian ini adalah penelitian kualitatif dengan metode deskriptif yang mengambil lokasi di Panti Sosial Bina Grahita Harapan Ibu Padang. Informan penelitian berjumlah sepuluh orang yang ditentukan dengan cara purposive sampling. Mereka adalah pendidik dan pembimbing serta anak tunagrahita. Data dikumpulkan melalui observasi, wawancara dan studi dokumentasi. Keabsahan data ditentukan dengan triangulasi sumber dan triangulasi teknik, data yang diperoleh dianalisis dengan tahap-tahap mereduksi data, menyajikan data dan menarik kesimpulan. Hasil penelitian menunjukkan bahwa bentuk-bentuk kemandirian pada anak seperti kemandirian emosi dan kemandirian sosial ditemukan pada saat proses belajar dan kegiatan di asrama. Hambatannya yaitu kesulitan dalam berkomunikasi dengan anak dan pemahaman akan sikap mandiri pada anak. Usaha untuk mengatasi hambatan tersebut dengan memberi pengertian, kasih sayang serta nasehat yang nanti perlahan akan dipahami oleh anak. Proses ini dilakukan secara terus menerus dan berkelanjutan. Oleh karena itu penguatan pendidikan karakter mandiri bagi anak berkebutuhan khusus tunagrahita diperlukan agar anak bisa mengurus diri sendiri tanpa bantuan orang lain.

Kata Kunci: Pendidikan Karakter Mandiri, Anak Berkebutuhan Khusus, Tunagrahita, Panti Sosial

\section{ABSTRACT}

This research is motivated by the importance of strengthening the independent character education of children with special needs. The research objective is to identify the forms, obstacles and efforts of educators and mentors in strengthening the independent character education of mentally retarded children. This type of research is a qualitative research with descriptive methods. The research take place at the Bina Grahita Harapan Ibu Social Institution in Padang city. Ten informants of the study were determined by purposive sampling. They are educators, mentors and mentally retarded children. Data collected 
through observation, interviews and documentation studies. The validity of the data is determined by triangulation of informant and technical triangulation. The data obtained are analyzed through: reducing data, presenting data and drawing conclusions. The results showed that the forms of independence in children are emotional and social found during the learning process and activities in the dormitory. The obstacles are communicating and understanding of independent attitude of children. Efforts to overcome these obstacles by giving understanding, affection and advice which will slowly be understood by children. This process is carried out continuously. Therefore, the strengthening of independent character education for children with special mental retardation is needed so that children can take care of themselves without the help of others.

Keywords: Independent character education, children with special needs for mental dezzeloment, social institution

This work is licensed under the Creative Commons Attribution-ShareAlike 4.0 International License. @2020 by author.

Received: Mei 22019

Revised: Agt 262019

Accepted: Jun 112020

\section{PENDAHULUAN}

Kualitas sumber daya manusia sangat menentukan keberhasilan suatu bangsa. Manusia antara yang satu dengan yang lain memiliki sesuatu yang membedakan dirinya dengan orang lain. Salah satu perbedaan tersebut dapat dilihat melalui karakternya. Karakter merupakan tabiat atau kepribadian yang dimiliki tiap manusia dan membedakannya dengan yang lain. Karakter dapat dimaknai sebagai nilai dasar yang membangun pribadi seseorang, terbentuk baik karena pengaruh hereditas maupun pengaruh lingkungan, yang membedakannya dengan orang lain, serta diwujudkan dalam sikap dan perilakunya dalam kehidupan sehari-hari (Samani dan Hariyanto, 2012:43).

Undang-undang No. 20 Tahun 2003 Pasal 23 tentang sistem pendididkan nasional menyebutkan bahwa pendidikan khusus (pendidikan luar biasa) merupakan pendidikan bagi peserta didik yang memiliki tingkat kesulitan dalam mengikuti prose pembelajaran karena kelainan fisik, emosional, mental dan sosial. Ketetapan UU ini secara jelas menyatakan bahwa anak penyandang kelainan perlu memperoleh kesempatan yang sama dengan yang diberikan kepada anak normal lainnya dalam hal pendidikan dan pengajaran.

Dalam dunia pendidikan, anak berkebutuhan khusus merupakan sebutan bagi anak yang memiliki kekurangan, tidak seperti anak pada umumnya tanpa selalu menunjukan pada ketidakmampuan emosi, mental dan fisisk. Anak dengan kebutuhan khusus merupakan anak yang mengalami kelainan ataupun penyimpangan fisik, mental maupun karakteristik perilaku sosialnya (Alimin: 2004). Sementara itu, anak tunagrahita adalah anak yang 
memiliki keterbatasan dan kecerdasan intelektual dibawah rata-rata. Anak tunagrahita dapat disebut juga anak yang tidak mampu beradaptasi dengan lingkungan normal dan membutuhkan layanan, perawatan, supervisi, kontrol dan dukungan dari pihak luar (Mumpuniarti, 2007:17). Klasifikasi anak tunagrahita meliputi anak tunagrahita ringan, sedang, dan berat.

\section{Panti Sosial Bina Grahita Harapan Ibu memiliki anak} tunagrahita berjumlah sekitar 100 anak berumur 13-30 tahun. Rata-rata anak tersebut berasal dari wilayah Provinsi Sumatera Barat. Anak-anak tunagrahita ini memiliki beberapa klasifikasi mental; Debil/mampu didik dengan IQ 50 - 70 adalah anak yang mempunyai potensi intelegensia angka kecerdasan antara 50 - 57. Namun memiliki mental Age (MA) setingkat dengan anak-anak umur 8 12 tahun. Mereka mengalami kesukaran dalam mengikuti hal-hal yang abstrak, seperti: pelajaran membaca dan berhitung. Sementara itu, anak dengan kategori embisil / mampu latih dengan IQ 20 - 49 adalah anak yang mempunyai potensi intelegensia setara dengan usia $3-7$ tahun. Mereka tergolong mampu latih, mampu mengikuti hal-hal yang abstrak dan sederhana, tetapi masih harus dilatih seperti berpakaian, mencuci dan mengerjakan keterampilan-keterampilan sederhana. Jika dilihat dari jumlah anak dan klasifikasi anak di Panti Sosial Bina Grahita Harapan Ibu dapat dilihat dari tabel berikut ini:
Tabel 1 : Jumlah Anak Tunagrahita dan Klasifikasi

\begin{tabular}{|l|l|l|l|}
\hline No & Jenis Kelamin & Klasifikasi & Jumlah \\
\hline 1 & Laki-laki & Imbisil & 39 \\
\hline 2 & Perempuan & Imbisil & 45 \\
\hline 3 & Laki-laki & Debil & 12 \\
\hline 4 & Perempuan & Debil & 4 \\
\hline Jumlah & & 100 \\
\hline
\end{tabular}

Sumber: Tata Usaha Panti Sosial Harapan Ibu Tahun 2018

Berdasarkan tabel di atas, dapat diketahui bahwa klasifikasi anak di Panti terdapat 2 jenis yaitu imbisil dan debil. Jenis kelamin laki-laki dengan klasifikasi Imbisil berjumlah 39 orang dan dengan klasifikasi Debil berjumlah 12 orang, sedangkan jenis kelamin perempuan dengan klasifikasi Imbisil berjumlah 45 orang dan dengan klasifikasi Debil berjumlah 4 orang yang jumlah anak keseluruhan 100 orang anak.

Salah satu nilai karakter yang perlu dikembangkan adalah kemandirian. Di era sekarang ini nilai kemandirian merupakan salah satu nilai karakter yang perlu mendapatkan perhatian. Hal ini disebabkan bahwa di masa sekarang banyak keluarga yang memperlakukan anak dengan melayani sepenuhnya kebutuhan anak dari bangun tidur hingga tidur kembali. Apalagi anak-anak yang kehidupan sehari-harinya selalu didampingi oleh asisten rumah tangga karena orang tuanya sibuk bekerja di luar rumah.

Berdasarkan pengamatan penulis di Panti Sosial Bina Grahita Harapan Ibu Padang, penguatan pendidikan karakter mandiri masih sangat rendah. Anak-anak tersebut 
cenderung dibantu oleh pengasuh, walaupun sulit bagi mereka untuk mandiri tapi sampai kapan anak-anak tuna grahita harus mendapatkan bantuan dari pengasuhnya. Mereka harus belajar untuk mandiri agar kelak saat mereka keluar ke lingkungan sosial mereka tidak merepotkan orang dengan kehadiran mereka serta dapat bertanggung jawab pada dirinya. Sehingga, penulis tertarik untuk mengkaji lebih dalam persoalan pendidikan karakter di Panti Sosial Harapan Ibu ini.

Tujuan penelitian ini adalah untuk melihat dan mendeskripsikan bentuk prasangka masyarakat Pariaman terhadap etnis Tionghoa serta dapat bermanfaat bagi masyarakat dalam meminimalisir prasangka terhadap etnis yang berbeda. Penelitian ini juga sebagai pengetahuan bagi masyarakat yang belum mengetahui sebab adanya prasangka terhadap etnis yang berbeda dalam masyarakat serta sebagai acuan dalam menciptakan komunikasi lintas budaya yang efektif antar etnik, ras, suku dalam sebuah masyarakat agar solusi yang ditawarkan dapat terealisasikan.

\section{METODE PENELITIAN}

Jenis penelitian ini yaitu kualitatif dengan menggunakan metode deskriptif. Lokasi penelitian di Panti Sosial Bina Grahita Harapan Ibu (PSBGHI) Padang dengan jumlah informan penelitian sepuluh orang. Informan terdiri dari pendidik dan pembimbing serta anak tunagrahita. Lama observasi dan penelitian yang dilakukan dua bulan. Teknik pengumpulan data didapatkan melalui observasi, wawancara, dokumentasi dan studi kepustakaan.

\section{HASIL DAN PEMBAHASAN}

Panti Sosial Bina Grahita Harapan Ibu merupakan panti sosial yang terdiri dari anak berkebutuhan khusus tunagrahita dengan klasifikasi debil dan imbisil. Mereka kebanyakan berasal dari berbagai daerah di Sumatera Barat. Meskipun panti ini merupakan panti rehabilitasi sosial yang ditujukan kepada penyandang disabilitasi mental retardasi, akan tetapi nilai- nilai pendidikan karakter mandiri yang diterapkan bersifat universal dan tidak memaksakan kepada anak tunagrahita. Setiap anak yang ada di Panti, mempunyai bentuk karakter mandiri tersebut. Sama halnya seperti anak normal, akan tetapi mereka tidak terlalu bisa mengontrol dengan baik tingkah lakunya.

Kemandirian terdiri atas empat bentuk, yaitu: pertama, kemandirian emosi, yaitu kemampuan mengontrol emosi sendiri dan tidak tergantungnya kebutuhan emosi pada orang lain. Kedua, kemandirian ekonomi, yaitu kemampuan mengatur ekonomi sendiri dan tidak tergantungnya kebutuhan ekonomi pada orang lain. Ketiga, kemandirian intelektual, yaitu kemampuan untuk mengatasi berbagai masalah yang dihadapi. Keempat, kemandirian sosial, yaitu kemampuan untuk mengadakan interaksi dengan orang lain dan tidak tergantung pada aksi orang lain (Desmita, 2009: 186)

Beranjak dari teori ini, maka bentuk kemandirian di panti sosial bina grahita harapan ibu menunjukan kemandirian emosi yang kurang. Emosi bagi mereka sangat sulit dikontrol, bahkan sebagian dari mereka tidak memahami apa itu 
emosi. Anak embisil yang pola pikirnya seperti anak umur 3 atau 4 tahun sangat sulit mengontrol kemandirian emosi mereka. Sementara itu, bentuk kemandirian sosial anak tunagrahita di panti ini sudah cukup maksimal. Mereka sudah dapat beradaptasi dengan lingkungan sekitar, tetapi masih belum bisa dilepas begitu saja keluar tanpa adanya pengawasan.

Adapun hambatan yang ditemui dalam penguatan pendidikan karakter tentu tidak dapat dihindari, namun harus dicari solusinya. Pendidikan karakter adalah sesuatu yang penting, jika anak tidak dapat mandiri maka mereka akan dapat menganggu kehidupan orang di sekitar mereka. Beberapa permasalahan yang dihadapi, pertama, berasal dari diri pribadi anak. Mereka berasal dari keluarga yang berbeda dengan latar belakang masing-masing. Hal ini menimbulkan perbedaan pada anak baik dalam tingkah laku, sifat maupun kecerdasaan masing-masing anak. Kedua, permasalahan yang timbul dari faktor dana. Dalam menjalankan segala kegiatan di panti asuhan, terutama dalam hal makan, pakaian, pendidikan untuk anak-anak dibutuhkan biaya yang besar dan terus menerus. Kesemuanya ini menimbulkan masalah yang kemudian berdampak kepada pembentukan karakter anak.

Hal yang umum ditemukan oleh para pendidik maupun pembimbing di Panti Sosial Bina Grahita ini yaitu dalam mendidik, membimbing dan mengarahkan pendidikan karakter sehingga tidak menjadi berlarut-larut. Pendidik maupun pembimbing menyadari bahwa yang mereka hadapi adalah anak berkebutuhan khusus yang juga membutuhkan penanganan khusus. Pengasuhan yang diterapkan di Panti terkendala dalam kurangnya minat anak mengerjakan kegiatan yang biasanya sudah sering dilaksanakan secara mandiri.

Untuk mengatasi hambatan tersebut, pihak panti memiliki solusinya, walaupun dari penerapannya tidak maksimal. Dari segi pribadi anak, pendidik ataupun pembimbing tetap menjalankan perannya dalam memberikan pengasuhan. Mereka menerapkan konsep pendidikan yang tepat, dan mendapatkan dukungan dari pihak berwenang. Sebagaimana teori yang dipaparkan mengenai fungsi panti asrama Menurut Departemen Sosial Republik Indonesia, adalah: (1) sebagai lembaga pelayanan kesejahteraan bagi anak dalam melaksanakan pengasuhan alternative pengganti orang tua yakni pengasuhan yang berbasis keluarga pengganti yang dilaksanakan oleh pihak-pihak di luar keluarga ini atau kerabat anak; (2) sebagai pusat pelayanan kesejahteraan sosial anak yakni sebagai pemulihan, perlindungan, pengembangan dan pencegahan; (3) sebagai pusat data dan informasi serta konsultasi kesejahteraan sosial anak, (4) sebagai pusat pengembangan keterampilan yang bertujuan menumbuhkan usaha ekonomis produktif.

\section{KESIMPULAN}

Berdasarkan uraian diatas terkait dengan penguatan karakter mandiri anak berkebutuhan khusus tunagrahita yang lakukan di Panti Sosial Bina Grahita "Harapan Ibu" (PSBGHI) Padang, maka dapat ditarik 
kesimpulan bahwa terdapat dua bentuk penguatan karakter: yang pertama dari emosi dan yang kedua dari sosial. Bentuk penguatan pendidikan karakter mandiri di bidang emosi terbagi atas dua bentuk yaitu dengan memisahkan anak dan menjauhkannya dari anak lain sampai anak merasa tenang dan bersikap lemah lembut. Sedangkan pada bentuk penguatan pendidikan karakter mandiri di bidang sosial dilakukan dengan memberi mereka tanggung jawab dan peduli terhadap sesama serta membimbing anak untuk beradaptasi dengan anak lain.

Sementara itu, terdapat dua hambatan yaitu kesulitan dalam memberikan pemahaman sikap mandiri pada anak dan kesulitan dalam berkomunikasi dengan anak. Usaha yang dilakukan pendidik dan pembimbing dalam mengatasi hambatan penguatan pendidikan karakter mandiri, dengan cara menasehati dan bersikap lemah lembut. Pendidik dan pembimbing tetap berpegang pada konsep pendidikan yang telah diterapkan selama ini. Menyentuh anak dengan hangat serta memberi pengertian, kasih sayang serta nasehat yang nanti perlahan akan dipahami oleh anak. Pemberian nasehat ini dilakukan tidak hanya sekali namun terus menerus.

\section{DAFTAR PUSTAKA}

Desmita (2009). Psikologi Perkembangan Peserta Didik. Bandung: Rosdakarya Offset.

Mumpuniarti. (2007). Pendidikan Anak Slow Learner. Yogyakarta: Jurusan Pendidikan Luar Biasa Fakultas Ilmu Pendidikan Universitas Negeri Yogyakarta.
Samani Muchlas, Hariyanto. Konsep dan Model Pendidikan Karakter. (Bandung: PT. Remaja Rosdakarya. 2013.).

Alimin, Zaenal. 2004. "Reorientasi Pemahaman Konsep Pendidikan Khusus Pendidikan Kebutuhan Khusus dan Implikasinya Terhadap Layanan Pendidikan". Jurnal Asesemen Dan Intervasi Anak Berkebutuhan Khusus. Vol. 3 No 1. Hlm 52-63.

Undang-Undang No 20 Tahun 2003 Tentang Sistem Pendidikan Nasional 